\title{
Participation of ovarian $20 \alpha$-hydroxysteroid dehydrogenase in luteotrophic and luteolytic processes during rat pseudopregnancy
}

\author{
J. Matsuda*, K. Noda, K. Shiota and M. Takahashi \\ Department of Veterinary Physiology, Faculty of Agriculture, University of Tokyo, Tokyo 113, \\ Japan
}

\begin{abstract}
Summary. In normal rats, before Day 12 of pseudopregnancy, minimal levels of 20aHSD activity were detected in functional CL whereas those in the residue were 3-5 times higher. When ovulation was blocked for more than 2 weeks by placing rats in a continuously lit environment before the induction of pseudopregnancy, only minimal levels of $20 \alpha$-HSD activity were detectable in the functional CL and residue before Day 12. In normal pseudopregnant rats, there was a linear increase in $20 \alpha-H S D$ activity from Day 12 to 15 in the functional $\mathrm{CL}$ and residue, but the rate of elevation was much higher in functional CL. This tendency was much more clear-cut in rats in the continuous lighting. In immature rats in which pseudopregnancy was induced by PMSG and hCG treatment, $20 \alpha-H S D$ activity peaked twice. The first small peak was attributed to the early regression of some of the large number of corpora lutea, and the changes in $20 \alpha-H S D$ activity in most of the corpora lutea paralleled those in rats in continuous lighting. Bromocriptine abolished the prolactin surges, and in normal pseudopregnant rats an increase in 20a-HSD activity in functional CL started from $12 \mathrm{~h}$ and the rate of the increase was accelerated from $36 \mathrm{~h}$ afterwards, while a relatively small increase was observed in the residue at $18 \mathrm{~h}$ and later. These results suggest that, in the early-middle phase of pseudopregnancy, 20 $\alpha$-HSD activity in the functional CL is suppressed under the control of prolactin and at the end of pseudopregnancy 20 $\alpha$-HSD activity appears mainly in the functional CL without suppressive action of prolactin.
\end{abstract}

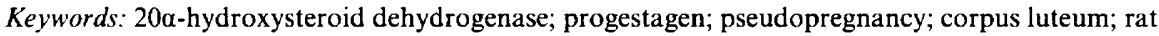

\section{Introduction}

Ovarian $20 \alpha$-hydroxysteroid dehydrogenase (20 $\alpha$-HSD) (EC 1.1.1.149) mediates the catabolism of

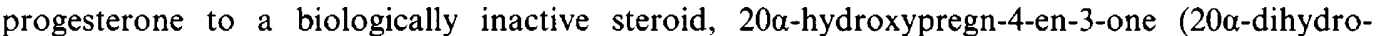
progesterone or 20a-OHP) (Wilcox \& Wiest, 1960; Wiest \& Forbes, 1964). During pregnancy or pseudopregnancy in the rat, ovarian secretory rate of progesterone is inversely correlated with that of $20 \alpha$-dihydroprogesterone (Hashimoto et al., 1968), and it is generally believed that this relationship between two progestagens is regulated by ovarian 20a-HSD (Wiest et al., 1968). Pupkin et al . (1966) reported the distribution of this enzyme in the rat ovary during normal oestrous cycles and found that relatively older corpora lutea $(C L)$ possessed high enzyme activity. It is therefore presumed that during pseudopregnancy the age or functional state of the $C L$ is well correlated with changes in $20 \alpha$-HSD activity, although the details still remain to be clarified.

In the present study, changes in $20 \alpha$-HSD activity of functional CL and the remainder of the ovary were investigated with reference to peripheral progestagen concentrations throughout pseudopregnancy. In addition to normal rats, we used other preparations in which only one generation of

*Present address: Department of Veterinary Science, National Institute of Health, Tokyo 141, Japan. 
CL was generated in the ovary. The effect of treatment with bromocriptine, a dopamine agonist, was also investigated to clarify the effect of prolactin on $20 \alpha-\mathrm{HSD}$ activity.

\section{Materials and Methods}

\section{Animals}

Animals used were of the Wistar-Imamichi strain and bred in our laboratory. Food and water were available ad libitum. Lighting was controlled automatically, giving $14 \mathrm{~h}$ of light (lights on at $05: 00 \mathrm{~h}$ ) and $10 \mathrm{~h}$ of darkness, except for Group $\mathrm{L}$ rats as mentioned below. The room temperature was kept at $23 \pm 1{ }^{\circ} \mathrm{C}$.

Group N. Rats, 2-4 months old, that had shown more than 2 normal vaginal cycles were used. Pseudopregnancy was induced by stimulating the uterine cervix with a glass rod for $1 \mathrm{~min}$ between 18:00 and 19:00 $\mathrm{h}$ on the day of prooestrus. The day following cervical stimulation was designated Day 0 of pseudopregnancy. Some of the rats were treated with bromocriptine (Sandoz, Ltd, Basle, Switzerland) s.c. at a dose of $150 \mu \mathrm{g} / 0 \cdot 1 \mathrm{ml} 3 \%$ tartaric acid solution at 00:00 h on Day 4 of pseudopregnancy.

Group $L$. Rats which had shown regular 4-day oestrous cycles for at least 10 days under a light regimen of $14 \mathrm{~h}$ light and $10 \mathrm{~h}$ darkness were transferred to an isolated room in which continuous lighting was supplied. Ovulation and subsequent pseudopregnancy were induced by cervical stimulation between 18:00 and 19:00 h (Murakami et al., 1978) in a group of these animals which had shown continual vaginal oestrus for 14-16 days. The day following cervical stimulation was designated Day 0 of pseudopregnancy.

Group I. Normal rats, 23-26 days old, were injected with 50 i.u. PMSG (Sankyo Zoki Co. Ltd, Tokyo, Japan) and $25 \mathrm{i} . u$. hCG (Sankyo Zoki Co. Ltd) $72 \mathrm{~h}$ later to induce pseudopregnancy after the occurrence of superovulation (Parlow, 1958; Tan \& Robinson, 1977). Each hormone preparation was dissolved in $0.9 \%(\mathrm{w} / \mathrm{v}) \mathrm{NaCl}(0.2 \mathrm{ml})$ and injected s.c. between 18:00 and 18:30 h.

\section{Collection of functional luteal tissue}

Group N. Ovaries were separated into functional corpora lutea $(\mathrm{CL})$ and the remaining tissue (residue) which consisted of old CL and non-luteal tissue. The ovaries of these animals contained 3-4 generations of CL: 5-10 of the largest $C L$ were selected as functional $C L$ and these were enucleated with tweezers.

Group $L$. New CL were enucleated, and were easily identifiable from old ones since ovulation had not occurred for at least 2 weeks.

Group I. Usually, $>30 \mathrm{CL}$ and a few follicles were present in each ovary of these rats. The 15 biggest corpora lutea were enucleated and used for the experiments.

\section{Blood collection and ovarian cytosol preparation}

Rats were killed by decapitation between 11:00 and 15:00 h except as otherwise indicated. Blood samples collected from trunks were allowed to clot at room temperature for several hours and centrifuged for $15 \mathrm{~min}$ at $1500 \mathrm{~g}$. The sera thus obtained were stored at $-20^{\circ} \mathrm{C}$ until hormone assays. The ovaries were removed, freed from adhering tissues and weighed. Functional $\mathrm{CL}$ and residue were separated as described above within $30 \mathrm{~min}$ after killing the animals, then homogenised with a Potter-type Teflon-glass blender in $500 \mu \mathrm{l} 100 \mathrm{~mm}-\mathrm{Tris}-\mathrm{HCl}$ (pH 8.0) containing 1 mM-EDTA and $5 \mathrm{~mm}$-dithiothreitol, and centrifuged at $105000 \mathrm{~g}$ for $60 \mathrm{~min}$. Then the cytosol fraction (supernatant) was filtered through a fibre-glass filter (GC 50; Toyo Roshi Co., Tokyo, Japan) to remove any insoluble substances including fat. All of these procedures were performed at $4^{\circ} \mathrm{C}$.

\section{Hormone assays}

Serum progesterone and $20 \alpha$-dihydroprogesterone concentrations were determined by radioimmunoassays using specific antibodies originally raised in our laboratory as described previously (Takahashi et al., 1980; Matsuyama et al., 1987). Progesterone and 20a-dihydroprogesterone were purchased from Sigma Chemical Co., St Louis, MO, USA. Tritium-labelled progesterone and 20a-dihydroprogesterone were from New England Nuclear, Boston, MA, USA. A serum sample $(0 \cdot 1 \mathrm{ml})$ was diluted to $1 \mathrm{ml}$ with distilled water and extracted twice with $2 \mathrm{ml}$ diethyl ether, and the extracts were radioimmunoassayed without chromatography. The progesterone antiserum cross-reacts $0 \cdot 2 \%$ with $20 a$-dihydroprogesterone, $3.1 \%$ with corticosterone and $<1.0 \%$ with other common progestagens, androgens and corticoids. The $20 a$-dihydroprogesterone antiserum cross-reacts $0.1 \%$ with progesterone and $<1.0 \%$ with other common progestagens and corticoids. The minimal detectable levels of progesterone and $20 a$-dihydroprogesterone were both $50 \mathrm{pg}$. The within- and between-assay coefficients of variation for each assay did not exceed $7 \%$. 


\section{Measurement of 20a-hydroxysteroid dehydrogenase activity}

The activity of 20a-hydroxysteroid dehydrogenase was measured spectrophotometrically by the method of Wiest et al. (1968) with a few modifications. The $20 \alpha$-dihydroprogesterone (20a-hydroxypregn-4-en-3-one), $30 \mu \mathrm{M}$, was catalysed to progesterone in $100 \mu \mathrm{M}-\mathrm{Tris}-\mathrm{HCl}$ buffer ( $\mathrm{pH} 8.0$ ) containing $300 \mu \mathrm{M}-\mathrm{NADP}, 1 \mathrm{~mm}-\mathrm{EDTA}, 5 \mathrm{~mm}-$ dithiothreitol (DTT) and 3\% ethanol (used to solubilize the steroids). DTT and NADP were added immediately before use. The assay mixture $(500 \mu \mathrm{l})$ was warmed to $37^{\circ} \mathrm{C}$ in an assay cuvette, and then the enzyme reaction was initiated by introducing $25 \mu \mathrm{l}$ cytosol preparation into the cuvette with rapid mixing. The temperature during the assay was maintained at $37 \pm 0 \cdot 1^{\circ} \mathrm{C}$. Initial velocities of NADPH accumulation were recorded spectrophotometrically at $340 \mathrm{~nm}$ for $3 \mathrm{~min}$ with an Hitachi 100-60 spectrophotometer (a molar absorbance of 6220 at $340 \mathrm{~nm}$ was used to calculate NADPH concentrations). Enzyme activity was determined by defining 1 unit of enzyme as the amount capable of reducing $1 \mu \mathrm{mol}$ NADP per min at $37^{\circ} \mathrm{C}$.

\section{Protein assay}

Protein concentrations were determined using the Bio-Rad protein assay (Bio-Rad Laboratories, Richmond, CA, USA) originally developed by Bradford (1976).

\section{Statistical analysis}

Duncan's new multiple range test was used for statistical evaluation of the results. Differences at a probability of $P<0.05$ were considered to be statistically significant.

\section{Results}

\section{Group N (Figs la, 2a)}

An almost linear increase in ovarian cytosolic $20 \alpha$-HSD activity was found from Day 12 to Day 15 in the functional $C L$ and residue. Although only minimal amounts of $20 \alpha-H S D$ activity were detected in functional CL from Days 4 to 12 , activities detected in the residue were $3-5$ times higher.

The $20 \alpha$-dihydroprogesterone concentration decreased during the early phase of pseudopregnancy. A decrease in progesterone concentration from Day 12 to Day 15 coincided with a rapid rise in $20 \alpha$-dihydroprogesterone concentration.

Group L (Figs 1b, 2b)

Only extremely low activities of ovarian cytosolic 20a-HSD were detected from Days 4 to 12 in the functional CL and residue. An increase in the activity began on Day 12 and the rate of the increase was much higher in functional CL than in residue.

There was a high progesterone concentration from Days 4 to 8 and a rapid decrease from Days 12 to 15 . The serum $20 \alpha$-dihydroprogesterone concentration rose significantly at Day 15 .

\section{Group I (Figs 1c, 2c)}

The very low ovarian cytosolic $20 \alpha-H S D$ activity on Day 0 represents the value before the ovulation induced by hCG treatment. Between Days 0 and 4 , a small but significant increase was observed and a large increase occurred between Days 12 and 16.

The peak value of progesterone concentration on Day 4 was 10 times higher than that in Group $N$ rats. The highest $20 \alpha$-dihydroprogesterone concentration was 3 times higher than that in Group $\mathrm{N}$ rats.

There was a rapid increase in cytosolic progesterone concentration between Days 0 and 4 and high levels were maintained until Day 8 . Values of $20 \alpha$-dihydroprogesterone remained low until Day 12, when luteolysis was considered to occur (Fig. 3). 


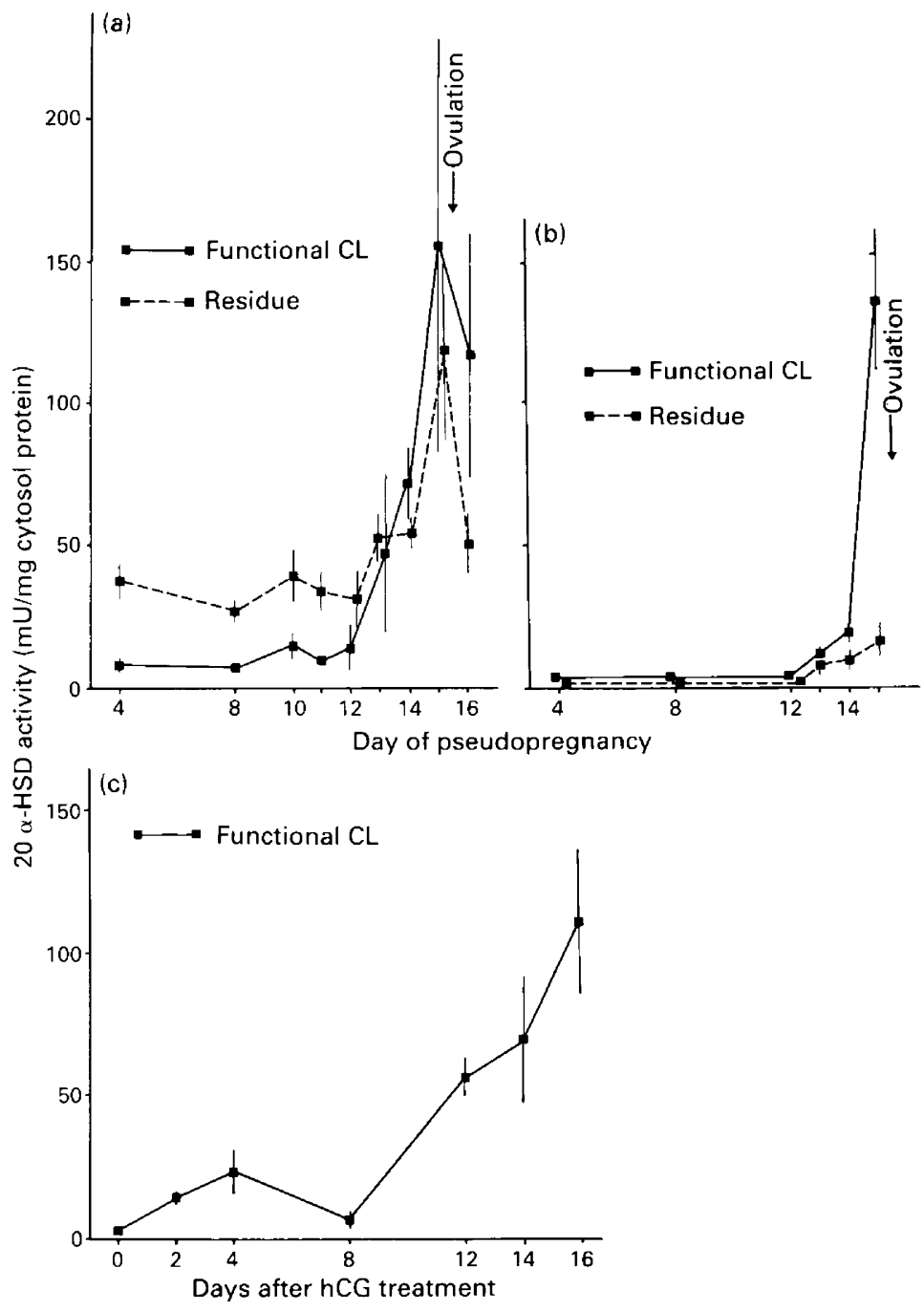

Fig. 1. Ovarian cytosolic 20 $\alpha$-hydroxysteroid dehydrogenase (20 $\alpha$-HSD) activities in functional $\mathrm{CL}$ and other ovarian tissues (residue) in rats in Groups $\mathrm{N}$ (a), L (b) and I (c). Each symbol represents the mean \pm s.e. for 4-5 animals. The activity of $20 \alpha-\mathrm{HSD}$ was expressed as $\mathrm{mU}$ enzyme activity/mg cytosol protein, with 1 unit of activity defined as the amount capable of reducing $1 \mu \mathrm{mol} \mathrm{NADP} / \mathrm{min}$ at $37^{\circ} \mathrm{C}$.

\section{Effects of bromocriptine}

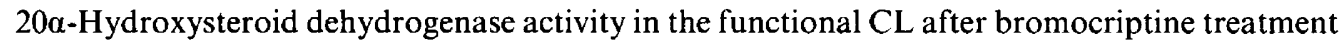
in Group $\mathrm{N}$ rats started to increase from $12 \mathrm{~h}$ and the rate of the increase was accelerated from $36 \mathrm{~h}$ after the treatment. The activity in the residue was increased $18 \mathrm{~h}$ after the treatment, but no significant changes in the activity could be observed from 18 to $60 \mathrm{~h}$ after the treatment when a rapid rise was observed in the functional CL (Fig. 4a).

Progesterone concentrations after bromocriptine treatment were lowered when $20 \alpha-\mathrm{HSD}$ activity in the functional CL rose (Fig. $4 b$ ). 


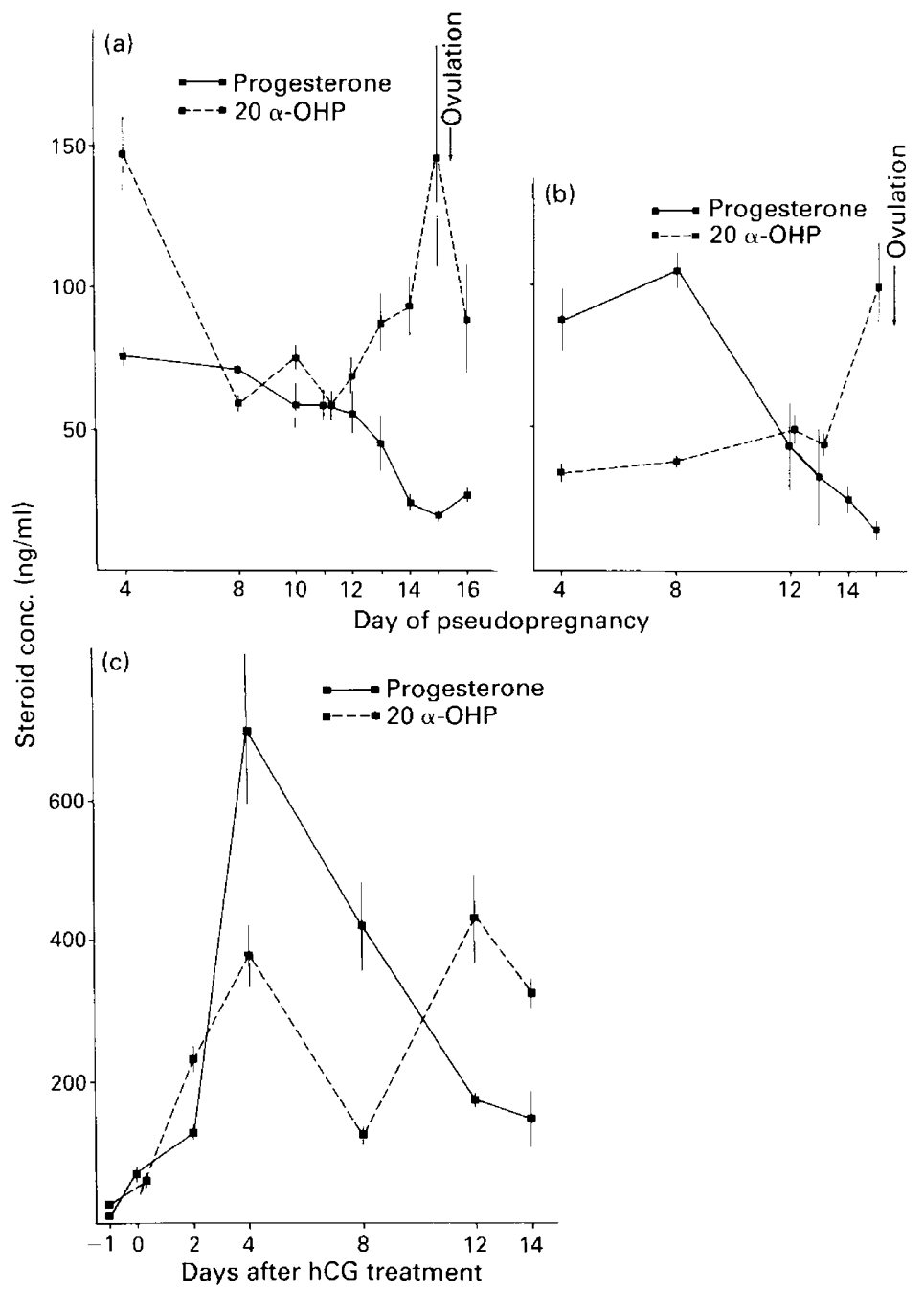

Fig. 2. Serum progesterone and $20 \alpha$-dihydroprogesterone (20 $\alpha$-OHP) concentrations in rats in Groups N (a), L (b) and I (c). Each symbol represents the mean \pm s.e. for 4-5 animals.

\section{Discussion}

The age of old crops of corpora lutea differs between the ovaries of rats in Groups $\mathrm{N}$ and $\mathrm{L}$. In Group $\mathrm{N}$ rats on Days 0 or 15 of pseudopregnancy for example, the age of the latest crop of corpora lutea carried over from the preceding oestrous cycles is 4 or 19 days, respectively. On the other hand, in Group L rats, the corresponding age is 16 or 31 days. Pupkin et al. (1966) observed histochemically that the $20 \alpha$-HSD activity during oestrous cycles began to appear at 3.5 days of age in newly generated corpora lutea and remained at least until the end of the following 2 cycles, i.e. for 9.5 days. In Group L rats, 20 $\alpha$-HSD activity was extremely low in non-luteal tissue (residue) in comparison with the moderate activity observed in the residue of the Group N rat ovary. 20a-HSD activity present in residual tissue during early pseudopregnancy in normal rats may depend upon the old corpora lutea which are carried over from the previous oestrous cycle, and the elevation of $20 \alpha-H S D$ activity at the end of pseudopregnancy may occur specifically in the new corpora lutea. 


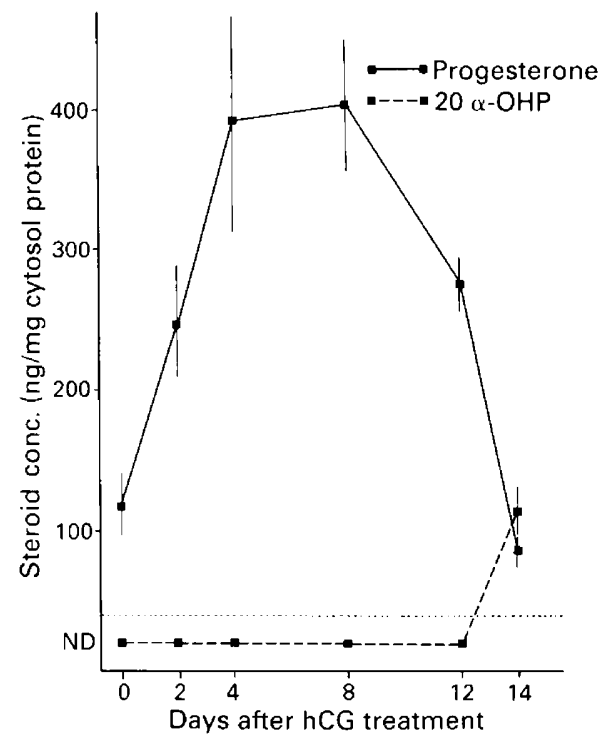

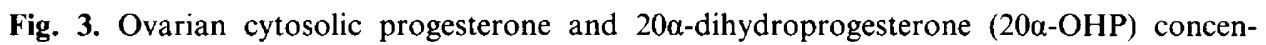
trations in Group I rats. Each symbol represents the mean \pm s.e. for 4-5 animals. Broken line shows the lower limit of the $20 a$-dihydroprogesterone assay.

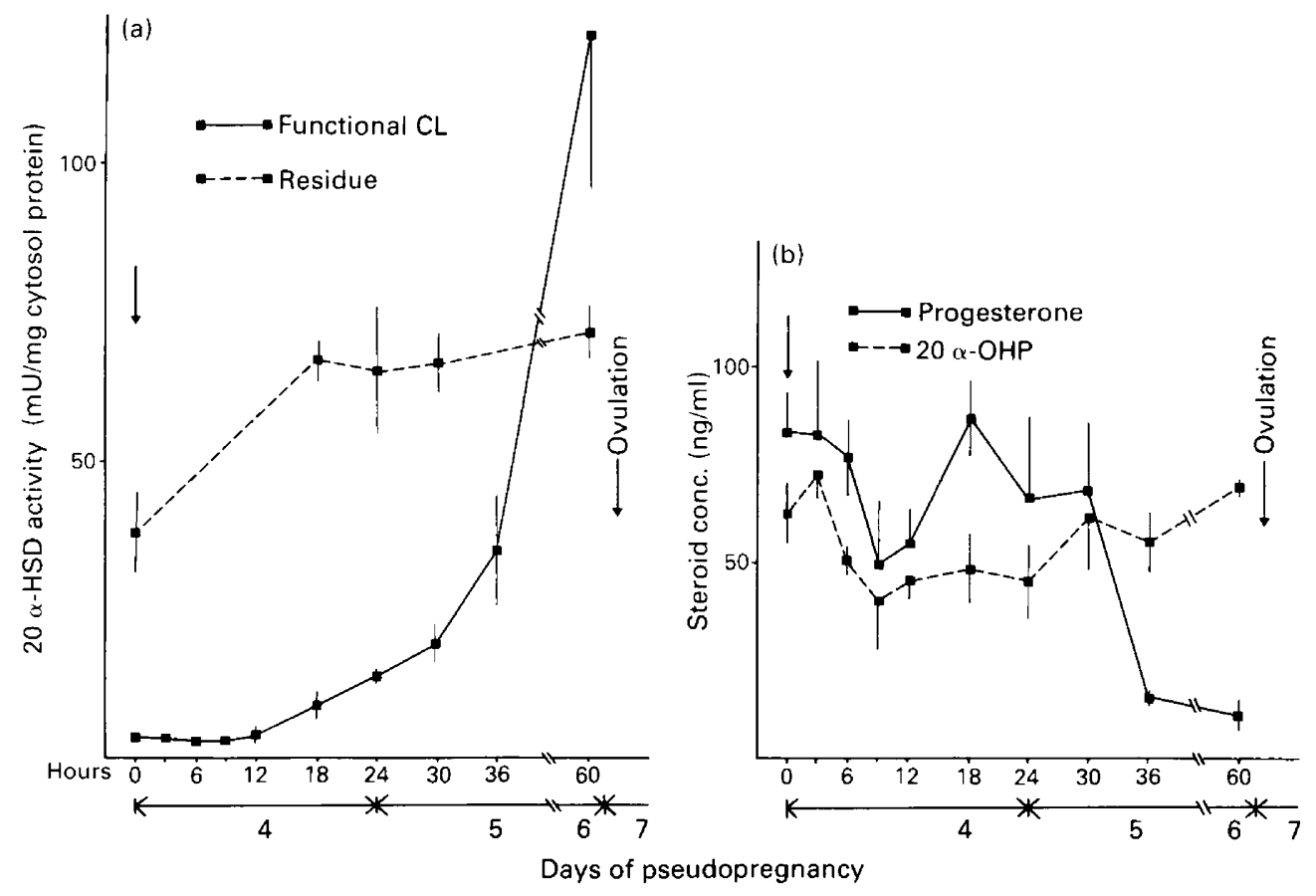

Fig. 4. Effects of bromocriptine treatment (arrow) in Group $\mathrm{N}$ rats on (a) ovarian cytosolic $20 \alpha$-hydroxysteroid dehydrogenase (20a-HSD) activities in functional corpora lutea and other ovarian tissues (residue), and (b) serum progesterone and $20 \alpha$-dihydroprogesterone concentrations. Each symbol represents the mean \pm s.e. for 3-5 animals. The activity of 20a-HSD was expressed as $\mathrm{mU}$ enzyme activity/mg cytosol protein, with 1 unit of activity defined as the amount capable of reducing $1 \mu \mathrm{mol} \mathrm{NADP} / \mathrm{min}$ at $37^{\circ} \mathrm{C}$. 
This observation reaffirms the earlier report of Wiest et al. (1968) and is also supported by the results of bromocriptine treatment (see below).

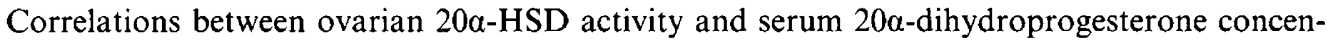
tration in pregnant and pseudopregnant rats have been studied (Wiest et al., 1968; Hashimoto \& Wiest, 1969). The patterns of ovarian $20 \alpha-H S D$ activity and serum progestagen concentrations in Group $\mathrm{N}$ rats are consistent with these previous investigations. It is generally believed that old corpora lutea retain a high level of $20 \alpha$-HSD activity, and are carried over to contribute to the high serum $20 \alpha$-dihydroprogesterone concentrations in the early-middle phase of pseudopregnancy (Day 0-Day 12); the new corpora lutea regress and acquire a high 20 $\alpha$-dihydroprogesterone content at the end of pseudopregnancy (Days 13-15).

In Group $L$ rats, however, relatively high concentrations of serum $20 \alpha$-dihydroprogesterone were maintained up to Day 12 of pseudopregnancy, although there was an extremely low ovarian $20 \alpha$-HSD activity. Moreover, as shown in the Group I rats, the peripheral serum progestagen concentrations were clearly different from the cytosolic concentrations. 20 $\alpha$-HSD activity has been found in mature T lymphocytes (Weinstein, 1977) and several other tissues, such as adrenal gland (Matthijssen et al., 1964), liver (Recknagel, 1957) and placenta (Purdy et al., 1964). Lu \& Judd (1982) have also reported that extra-ovarian system(s) can convert large amounts of circulating progesterone into $20 \alpha$-dihydroprogesterone. Peripheral progestagen concentration is therefore not necessarily correlated with ovarian $20 \alpha-\mathrm{HSD}$ activity.

In the immature rats, the serum $20 \alpha$-dihydroprogesterone concentration peaked twice on Days 4 and 12 of pseudopregnancy, and this fluctuation was correlated with $20 \alpha-H S D$ activity. The significance of these two peaks of $20 \alpha$-HSD activity in immature rats remains to be studied further. However, the close relationship between serum $20 \alpha$-dihydroprogesterone concentration and ovarian $20 \alpha$-HSD activity suggests that a proportion of the corpora lutea actually regress on Day $3 \cdot 5$, similar to the situation during normal oestrous cycles, and that the other corpora lutea remain functional throughout the normal period of pseudopregnancy. The occurrence of $20 \alpha-\mathrm{HSD}$ activity in the luteal tissue is thought to be irreversible (Wiest et al., 1968). If this is the case, the decrease in $20 \alpha$-HSD activity on Day 8 cannot be explained by a transient inhibition of activity, but rather that the corpora lutea in the immature rat appear to consist of two types with different functions. One type of corpora lutea might be refractory to prolactin by which $20 \alpha-H S D$ activity is thought to be suppressed, and the other type might be sensitive to prolactin.

On Day 4 of pseudopregnancy, prolactin surges occur early in the morning (nocturnal surge) and in the evening (diurnal surge) (Smith et al., 1975; Murakami et al., 1979). Prolactin release from the anterior pituitary gland is tonically inhibited by dopamine (MacLeod \& Lehmeyer, 1974). In the present study, administration of bromocriptine, a dopamine agonist, at 00:00 h on Day 4 would have begun to inhibit the series of prolactin surges from the nocturnal surge on the same day. A marked increase in $20 \alpha-\mathrm{HSD}$ activity was observed in functional $\mathrm{CL}$ about $40 \mathrm{~h}$ after the last prolactin surge, but an increase in the residue was not so remarkable. This suggests that the $20 \alpha-$ HSD activity in the functional CL is effectively suppressed by the surge of prolactin and $20 \alpha-H S D$ activity appears mainly in the functional $\mathrm{CL}$ when prolactin surges are abolished.

The long latency, of about $40 \mathrm{~h}$, between prolactin withdrawal and the increase in $20 \alpha-\mathrm{HSD}$ activity is surprising. Saito et al. (1988) reported that macrophages or splenic adherent cells were involved in expression of the luteotrophic action of prolactin and this interposition of myelogenic cells between prolactin and luteal cells is one possible explanation for this long latency.

At the end of pseudopregnancy, it is known that prolactin surges do not cease if serum progesterone concentrations are maintained experimentally at high levels (de Greef \& Zeilmaker, 1978; Murakami et al., 1979). Under this condition, or if the animals are treated with prolactin, luteolysis occurs at the scheduled time, i.e. at 2 weeks (Naito \& Suzuki, 1978; Takahashi et al. 1978). It is therefore generally believed that pseudopregnancy ends not as a result of extinction of prolactin surges but by refractoriness of the corpus luteum to prolactin, the action of which has been inhibiting $20 \alpha-H S D$ activity for 2 weeks. It is concluded that the refractoriness of the corpus luteum to 
prolactin causes an increase in 20a-HSD activity in newly formed corpora lutea, which in turn causes a decrease in progesterone secretion.

We thank Dr H. Sakai for helpful advice about measurement of $20 \alpha-H S D$ activity; and Dr D. B. Douglas for reading the manuscript.

\section{References}

Bradford, M.M. (1976) A rapid and sensitive method for the quantitation of microgram quantities of protein utilizing the principle of protein-dye binding. Analyt. Biochem. 72, 248-253.

de Greef, W.J. \& Zeilmaker, G.H. (1978) Regulation of prolactin secretion during the luteal phase in the rat. Endocrinology 102, 1190-1197.

Hashimoto, I. \& Wiest, W.G. (1969) Correlation of the secretion of ovarian steroids with function of a single generation of corpora lutea in the immature rat. Endocrinology 84, 873-885.

Hashimoto, I., Henricks, D.M., Anderson, L.L. \& Melampy, R.M. (1968) Progesterone and pregn-4-en$20 \alpha$-ol-3-one in ovarian venous blood during various reproductive states in the rat. Endocrinology 82, 333-341.

Lu, J.K.H. \& Judd, H.L. (1982) Silastic implants of progesterone produce high circulating levels of both progesterone and $20 \alpha$-hydroxyprogesterone in ovariectomized, adrenalectomized rats. Biol. Reprod. 26, 385-390.

MacLeod, R.M. \& Lehmeyer, J.E. (1974) Studies on the mechanism of the dopamine-mediated inhibition of prolactin secretion. Endocrinology 94, 1077-1085.

Matsuyama, S., Ohta, M. \& Takahashi, M. (1987) The critical period in which splenectomy causes functional disorder of the ovary in adult rats. Endocr. japon. 34, 849-855.

Matthijssen, C., Mandel, J.E. \& Seiden, P.T. (1964) Separation of a purified adrenal $20 \alpha$-hydroxysteroid dehydrogenase. Biochim. Biophys. Acta 89, 363-364.

Murakami, N., Takahashi, M. \& Susuki, Y. (1978) Conditions for establishment of reflex ovulation in light estrous rats. Endocr. japon. 25, 299-303.

Murakami, N., Takahashi, M. \& Suzuki, Y. (1979) Indispensable role of peripheral progesterone level for the occurrence of prolactin surges in pseudopregnant rats. Biol. Reprod. 21, 263-268.

Naito, H. \& Suzuki, Y. (1978) The rat estrous cycle associated with functional corpora lutea and the mechanism of its recurrence. Endocr. japon. 25, 367-376.

Parlow, A.F. (1958) A rapid bioassay method for LH and factors stimulating LH secretion. Fedn Proc. Fedn Am. Socs exp. Biol. 17, 402, abstr.

Pupkin, M., Bratt, H., Weisz, J., Lloyd, C.W. \& Balogh, K., Jr (1966) Dehydrogenase in the rat ovary. I. A histochemical study of $\Delta^{5}-3 \beta$ - and $20 \alpha$-hydroxysteroid dehydrogenase and enzymes of carbohydrate oxidation during the estrous cycle. Endocrinology 79, 316-327.

Purdy, R.H., Halla, M. \& Little, B. (1964) 20 $\alpha$-Hydroxysteroid dehydrogenase activity a function of hurnan placental 17ß-hydroxysteroid dehydrogenase. Biochim. Biophys. Acta 89, 557-560.

Recknagel, R.O. (1957) Adrenocortical steroid C-20keto reductase. J. biol. Chem. 227, 273-284.

Saito, S., Matsuyama, S., Shiota, K. \& Takahashi, M. (1988) Involvement of splenocytes in the control of corpus luteum function in the rat. Endocr. japon. 35, 891-898.

Smith, M.S., Freeman, M.E. \& Neill, J.D. (1975) The control of progesterone secretion during the estrous cycle and early pseudopregnancy in the rat: prolactin, gonadotropin and steroid levels associated with rescue of the corpus luteum of pseudopregnancy. Endocrinology 96, 219-226.

Takahashi, M., Shiota, K. \& Suzuki, Y. (1978) Preprogramming mechanism of luteinizing hormone in the determination of the lifespan of the rat corpus luteum. Endocrinology 102, 494-498.

Takahashi, M., Murakami, N., Naito, H. \& Suzuki, Y. (1980) Blockade of pseudopregnancy in the rat by treatment with antiprogesterone serum. Biol. Reprod. 22, 423-429.

Tan, C.H. \& Robinson, J. (1977) The superovulated rat: its use as a model in studies on the acute steroidogenic effects of luteinizing hormone. Endocrinology 101, $396-402$.

Weinstein, Y. (1977) 20 $\alpha$-Hydroxysteroid dehydrogenase: a T lymphocyte-associated enzyme. J. Immunol. 119, 1223-1229.

Wiest, W.G. \& Forbes, T.R. (1964) Failure of $20 \alpha$-hydroxy$\Delta^{4}$-pregnen-3-one and $20 \beta$-hydroxy- $\Delta^{4}$-pregnen-3one to maintain pregnancy in ovariectomized mice. Endocrinology 74, 149-152.

Wiest, W.G., Kidwell, W.R. \& Balogh, K., Jr (1968) Progesterone catabolism in the rat ovary: a regulatory mechanism for progestational potency during pregnancy. Endocrinology 82, 844-859.

Wilcox, R.B. \& Wiest, W.G. (1960) Comparative effectiveness of progesterone and 4-pregnen-20 $\alpha$-ol-3-one in the development of deciduomata. Endocrinology 82, 844-859. 